\title{
Incretin Hormones and Insulin Responses During OGTT in Newly Diagnosed T2DM Patients
}

\author{
Jhuma KA ${ }^{1}$, Giasuddin $\mathrm{ASM}^{2}$, Haq $\mathrm{AMM}^{1}$, Huque $\mathrm{MH}^{1}$ \\ ${ }^{l}$ Medical College for Women \& Hospital, Dhaka, Bangladesh; \\ ${ }^{2}$ Medical Research Unit, Medical and Health Welfare Trust, Dhaka, Bangladesh
}

e-mail: khadijajhuma2017@gmail.com

\begin{abstract}
Several research groups have reported variable results about incretin effects of glucose-dependent insulinotropic polypeptide (GIP) and glucagon-like peptide-1(GLP-1) particularly, as well as cytokines balance in type 2 diabetes mellitus (T2DM). The present case-control prospective interventional study was conducted in 2014-2015 at Medical College for Women \& Hospital, Dhaka, investigating responses of incretin hormones and insulin to oral glucose tolerance test (OGTT) in Bangladeshi subjects. Blood samples were collected from 36 OGTT positive adult T2DM patients (Pt) and 30 normal adults (NC) at ' 0 ' minute (fasting) and at 2 hours after OGTT. Routine laboratory investigations in blood were done and special parameters in serum, i.e. insulin, HGH, TSH, GIP and GLP-1 were analyzed using enzyme immunoassay kits. Pt had FBG and BG2Hr levels much higher than NC $(p<0.001)$. In Pt, F-Insulin and Insulin2Hr were much lower than NC subjects $(p<0.001)$, although Insulin2Hr level was higher than F-Insulin level in Pt. FGIP ( $p=0.309)$ and F-GLP-1 $(p=0.984)$ levels were similar between Pt and NC. Interestingly, NC responded to OGTT by increasing GIP2Hr and GLP-1,2Hr levels about 3 times, whereas Pt responded by raising about 1.5 times only compared to F-GIP and F-GLP-1 $(p<0.001)$. Reduced insulin levels, both fasting and postprandial, were possibly due to decreased responses of GIP and GLP-1 to glucose load in T2DM patients. Further studies with a larger sample size including cytokines are warranted.
\end{abstract}

Keywords: Diabetes mellitus, T2DM, GIP, GLP-1

\section{Introduction}

Diabetes mellitus (DM) is a serious global health issue with type 2 diabetes mellitus (T2DM) accounting for about $90-95 \%$ of all cases. It is estimated that about $7.8 \%$ of the world population aged between 20 and 79 years will have T2DM by 2030..$^{1,2}$

Although glucose-tolerant individuals are capable of adjusting their insulin secretion to their actual insulin sensitivity, people with T2DM are incapable of doing so. Beta-cell failure is the hallmark of this disease, although failure may be precipitated by the development of insulin resistance. In healthy subjects, a considerable part of the postprandial insulin response is due to the actions of the incretin hormones, particularly glucagon-like peptide 1 (GLP-1) and glucose-dependent insulinotropic polypeptide (GIP). Together, these two hormones are mainly responsible for the socalled incretin effect. ${ }^{3}$ Although frequently ignored, the effect strongly depends on the dose of glucose. A convenient way of describing the effect is to calculate the gastro-intestinally mediated glucose disposal (GIGD). ${ }^{4}$

A convenient way of describing the effect, which depends on the dose of glucose, is to calculate the gastro-intestinally mediated glucose disposal (GIGD). ${ }^{4,5}$ Here, the amount of glucose required by intravenous infusion to 
copy the glucose excursions after the oral load is related to the oral load. Thus, if $25 \mathrm{~g}$ is required to copy a $75 \mathrm{~g}$ oral glucose load, the GIGD amounts to $100 \times(75-25) / 75=66 \%$. In other words, mechanisms associated with and activated by the oral ingestion resulted in a disposal of $75-25=50 \mathrm{~g}$ of the ingested glucose. ${ }^{5}$

Most of the GIGD in healthy subjects is accounted for by the actions of the incretin hormones, but inhibition of hepatic glucose production by suppression of glucagon secretion, hepatic uptake of glucose from the portal vein, and gut-brain or liver-brain reflex activity may also play a role. The healthy human body has a remarkable capacity to handle the intake of increasing amounts of glucose and is therefore capable of maintaining almost unchanged postprandial glucose excursions, regardless of the oral load. In people with T2DM, this ability is dramatically reduced as illustrated by calculation of the GIGD, which may be close to zero. ${ }^{5}$ The almost complete loss of GIGD is typically accompanied by a greatly reduced difference between the insulin responses to the oral and the intravenous glucose load, i.e. the incretin effect. ${ }^{5,6}$ As indicated by the almost complete loss of GIGD, the incretin effect remaining in the patients with T2DM has little effect on glucose disposal, probably as a result of the simultaneously occurring insulin resistance. The loss of incretin effect is therefore likely to contribute importantly to the postprandial hyperglycemia in T2DM. Research carried out by several groups during the last decades has indicated that the incretin effect is mediated mainly by GIP and GLP-1 and no other gut hormones fulfill all criteria to act as incretin hormones, i.e. being secreted during glucose ingestion and being capable of stimulating insulin secretion during similar glycemic levels and in those concentrations that are reached during glucose ingestion. ${ }^{5-10}$

The concentrations of GIP have been reported to be elevated, decreased and unchanged in patients with T2DM. Toft-Nielsen et al found slightly decreased postprandial GIP concentrations in a large group of T2DM patients compared with a matched control group of nondiabetic subjects. ${ }^{11}$ A major secretary defect regarding GIP secretion did not seem to exist in T2DM. When GLP-1 was identified as the other important incretin hormone, it was relevant to evaluate GLP-1 secretion in T2DM also. $^{12}$ Toft-Nielsen et al found a pronounced impairment of the postprandial GLP-1 response, particularly during the later postprandial phase (after the first $60 \mathrm{~min}$ ). ${ }^{11}$ The decreased secretion was thought to be secondary to the disease, since it was noted only in the diabetic twins or identical twins discordant for diabetes.$^{13,14}$ In addition, first-degree relatives of T2DM patients exhibited normal 24-h GLP-1 profiles. ${ }^{15}$ Some other studies could not confirm decreased GLP-1 responses in T2DM patients and reported contradictory results. ${ }^{16,17}$

So, it needs to be settled through further research in human. Literature survey has indicated that so far no study has been done or reported on incretin hormones and their responses to glucose load in Bangladeshi patients with T2DM. Thus, it was intended to investigate serum incretin hormones (GIP, GLP1), insulin, thyroid stimulating hormone (TSH) and human growth hormone (HGH) status and their responses to oral glucose load (OGTT) in Bangladeshi T2DM patients and healthy subjects.

\section{Materials and Methods}

This case-control prospective interventional study conducted during the period from November, 2013 to June, 2014 at the Medical Research Unit (MRU) of the Medical \& Health Welfare Trust (MHWT), Uttara, Dhaka. Patients with newly diagnosed T2DM were included in the study. Suspected patients with T2DM had undergone oral glucose tolerance test (OGTT) after fasting. Blood samples were collected from individual patients at ' $\mathrm{O}$ ' min (Fasting) and at 2 
Hrs (120 min) after OGTT. Samples were aliquoted for routine analyses and special research investigations. Among the routine analysis, glucose level and other usual routine tests in blood, serum and urine were done. Serum aliquots were preserved for a short time at $-20^{\circ} \mathrm{C}$ to $-30^{\circ} \mathrm{C}$ for incretin hormones, and other special investigations. A total of 36 OGTT positive adult patients (male: 15, female: 21) were included in this case - control prospective interventional study. Only newly diagnosed DM patients were included in this study. Those who had other diseases such as thyroid diseases, any endocrine diseases, renal diseases, hypertension, etc were excluded. And 30 normal healthy adults (male: 12, female: 18) were investigated in parallel as normal control subjects. Routine laboratory investigations such as blood glucose, CBP, HbA ${ }_{1 C}$, LFTs, TFTs, RFTs, etc were made according to usual clinical laboratory methods as practiced in the hospital laboratory. The special investigations, i.e. serum Insulin, TSH, HGH, GIP and GLP-1, were made by adopting enzyme immunoassay (EIA) methods using kits obtained from reputed commercial companies such as R\&D Systems (USA), Calbiotech (USA), Novatech (Germany) etc. Statistical analyses were perfomed by Paired t-test and Student's t-test using SPSS programme.

\section{Results}

The results of the laboratory investigations and their statistical analysis by Student's t-test for T2DM patients $(\mathrm{Pt})$ group and normal control (NC) subjects are stated in table-I. Before glucose load T2DM group showed lower levels of insulin [11.5 $\pm(4.8)$ vs 19.64 $\pm(7.08)]$, GIP $[60.1 \pm(12.2)$ vs $63.4 \pm(13.8)]$ and GLP$1[54.7 \pm(13.9)$ vs $60.8 \pm(13.4)]$ and at 120 minutes $(2 \mathrm{Hrs})$ after glucose load, the raise in were much lower than the healthy subjects in all the three parameters. The values were Insulin $[22.6 \pm(9.1)$ vs $59.1 \pm(21.2)]$, GIP $[119.3 \pm$ (22.9) vs $158.6 \pm(34.5)]$ and GLP-1[81.7 \pm (20.4) vs $164.5 \pm(40.3)]$ (table I). No significant differences were observed between $\mathrm{Pt}$ and $\mathrm{NC}$ for F-TSH, TSH 2Hrs, F-HGH and HGH 2Hrs $(p>0.05)$. At diagnosis, T2DM patients have low insulin and incretins at fasting state and post glucose stimulated values were also less than the healthy subjects. Therefore, the data support the concept that in T2DM, like that of insulin, incretins abnormality is also an early component in pathophysiology of diabetes.

\begin{tabular}{|c|c|c|c|c|c|c|c|c|}
\hline \multirow[t]{2}{*}{$\begin{array}{l}\text { Groups } \\
\text { compared }\end{array}$} & \multicolumn{2}{|c|}{$\begin{array}{l}\text { Glucose } \\
(\mathrm{mmol} / \mathrm{L})^{*} \\
\text { Mean } \pm \text { SD }\end{array}$} & \multicolumn{2}{|c|}{$\begin{array}{l}\text { Insulin } \\
(\mu \mathrm{IU} / \mathrm{ml})^{*} \\
\text { Mean } \pm \text { SD }\end{array}$} & \multicolumn{2}{|c|}{$\begin{array}{c}\text { GIP } \\
(\mathrm{pg} / \mathrm{ml})^{*} \\
\text { Mean } \pm \text { SD }\end{array}$} & \multicolumn{2}{|c|}{$\begin{array}{l}\text { GLP-1 } \\
(\mathrm{pg} / \mathrm{ml})^{*} \\
\text { Mean } \pm \text { SD }\end{array}$} \\
\hline & $\begin{array}{l}\text { FBG } \\
0 \mathrm{Hr} \\
\end{array}$ & $\begin{array}{l}\mathrm{BG} \\
2 \mathrm{Hr} \\
\end{array}$ & $\begin{array}{c}\text { F- Insulin } \\
0 \mathrm{Hr} \\
\end{array}$ & $\begin{array}{c}\text { Insulin } \\
2 \mathrm{Hr}\end{array}$ & $\begin{array}{c}\text { F-GIP } \\
0 \mathrm{Hr} \\
\end{array}$ & $\begin{array}{l}\text { GIP } \\
2 \mathrm{Hr}\end{array}$ & $\begin{array}{c}\text { F- GLP-1 } \\
0 \mathrm{Hr} \\
\end{array}$ & $\begin{array}{c}\text { GLP-1, } \\
2 \mathrm{Hr}\end{array}$ \\
\hline Healthy & 5.2 & 6.4 & $\begin{array}{l}19.64 \\
\end{array}$ & 59.1 & 63.4 & 158.6 & 60.8 & 164.5 \\
\hline $\begin{array}{l}\text { Subjects } \\
(\mathrm{NC}, \mathrm{n}=30)\end{array}$ & \pm 0.8 & \pm 0.7 & \pm 7.08 & \pm 21.2 & \pm 13.8 & \pm 34.5 & \pm 13.4 & \pm 40.3 \\
\hline $\begin{array}{l}\text { T2DM } \\
\text { Patients } \\
(\mathrm{Pt}, \mathrm{n}=36)\end{array}$ & $\begin{array}{l}10.9 \\
\pm 1.9\end{array}$ & $\begin{array}{l}14.6 \\
\pm 4.8\end{array}$ & $\begin{array}{l}11.5 \\
\pm 4.8\end{array}$ & $\begin{array}{l}22.6 \\
\pm 9.1\end{array}$ & $\begin{array}{c}60.1 \\
\pm 12.2\end{array}$ & $\begin{array}{l}119.3 \\
\pm 22.9\end{array}$ & $\begin{array}{c}54.7 \\
\pm 13.9\end{array}$ & $\begin{array}{c}81.7 \\
\pm 20.4\end{array}$ \\
\hline t-test: & & & & & & & & \\
\hline df & 64 & 64 & 64 & 64 & 64 & 64 & 64 & 64 \\
\hline$t$ & 13.11 & 9.20 & -5.52 & -9.36 & -1.03 & -5.52 & -0.021 & -10.79 \\
\hline $\mathrm{p}$ & $<0.001$ & $<0.00$ & $<0.001$ & $<0.001$ & 0.309 & $<0.001$ & 0.984 & $<0.001$ \\
\hline
\end{tabular}

*FBG: Fasting blood glucose; BG2Hr: Blood glucose at 2hrs of OGTT; F-Insulin: Fasting insulin; Insulin2 $\mathrm{Hr}$ : Insulin at $2 \mathrm{hrs}$ of OGTT; F-GIP: Fasting glucose-dependent insulinotropic polypeptide; GIP2Hr: Glucose-dependent insulinotropic polypeptide at $2 \mathrm{hrs}$ of OGTT; F-GLP-1: Glucagon-like peptide 1; GLP-1,2Hr: Glucagon-like peptide 1 at 2Hrs of OGTT;

\section{Discussion}

In this study, T2DM patients (Pt) had FBG $(p<0.001)$ and $\mathrm{BG} 2 \mathrm{Hr}(p<0.001)$ levels much higher than NC subjects $(p<0.001)$ which were expected (table-I). No significant differences were observed between $\mathrm{Pt}$ and $\mathrm{NC}$ for F-TSH $(p=0.927), \quad \mathrm{TSH} 2 \mathrm{Hr} \quad(p=0.413), \quad$ F-HGH $(p=0.532)$ and HGH2Hr $(p=0.773)$ levels. In Pt, F-Insulin $(p<0.001)$ and Insulin2 $\mathrm{Hr}(p<0.001)$ were much lower than NC subjects, although Insulin2Hr level was higher than F-Insulin level in Pt. It was observed that F-GIP $(p=0.309)$ and F-GLP-1 $(p=0.984)$ levels were similar between $\mathrm{Pt}$ and $\mathrm{NC}$ subjects. Interestingly, NC subjects responded to OGTT by increasing GIP2Hr and GLP-1,2Hr levels about 3 times compared to FGIP and F-GLP-1. In Pt, F-GIP and F-GLP-1 levels were also raised responding to OGTT but by about 1.5 times only (table-I).

Most of the GIGD in healthy subjects is accounted for by the actions of the incretin hormones, but inhibition of hepatic glucose production by suppression of glucagon secretion, hepatic uptake of glucose from the portal vein and gut-brain or liver-brain reflex activity may also play a role. There is no doubt that the incretin hormones play a major role in GIGD in healthy subjects and it can be 
concluded that the incretin effect plays a major role for normal glucose tolerance. In patient with T2DM, this ability is dramatically reduced as shown in our result similar to some other reports. ${ }^{5}$ The loss of incretin effect is therefore likely to contribute importantly to the postprandial hyperglycemia in T2DM.

Results of this study were the first to be reported from this geographical region. However, results were similar to those of Toft-Nielsen et al, who suggested that a major secretary defect regarding GIP secretion did not seem to exist in T2DM, but they reported pronounced impairment of the postprandial GLP-1 response in T2DM subjects, particularly during the later postprandial phase (after the first $60 \mathrm{~min}$ ). ${ }^{9}$ However, presence of some other unidentified incretin hormones not yet discovered cannot be ruled out. Holst et al concluded that the dramatic loss in T2DM patients of the ability to dispose of orally ingested glucose (GIGD) is related to the inability of the incretin hormones to increase insulin secretion after meal or glucose load. ${ }^{18,19}$ Several lines of evidence support that the loss of incretin effect is secondary to development of diabetes. ${ }^{19-22}$ However, more recent findings suggest that the loss of incretin effects in T2DM patients can only be explained by a specific loss of insulinotropic activity of the incretin hormones at physiological level. ${ }^{19,2325}$ In overt T2DM, the consequence of the impaired incretin effect is that the ability of the patients to efficiently dispose of orally as opposed to intravenously administered glucose is completely lost. ${ }^{19}$

Findings of this study, relatively reduced capacity of T2DM Patients to produce GIP and GLP-1 seemed to be relevant and interesting. These incretin responses may be linked to proinflammatory cytokines such as interleukin (IL)1 , IL-6, tumor neurosis factor- $\alpha$ (TNF- $\alpha$ ), etc. These cytokines are thought to impair insulin signalling and abnormally high levels of them are associated with insulin resistance and T2DM. ${ }^{26-30}$ However, conflicting and contrasting results of increase in postprandial plasma IL- 6 and TNF- $\alpha$ levels were reported in T2DM patients. ${ }^{24,31}$ The involvement of proinflammatory cytokines was substantiated by the observation that IL-1 blockade attenuates $\beta$-cell dysfunction by islet amyloid-induced inflammation in T2DM. ${ }^{32}$ It has been reported that TNF- $\alpha$ induced insulin resistance is associated with an elevated expression of IL-18 in human skeletal muscle tissue, which suggest, a possible role for IL-18 in the pathogenesis of TNF- $\alpha$ induced insulin resistance in humans. ${ }^{33,34}$ Also, it has been reported that antiinflammatory cytokines (IL-4, IL-10, IL-13, etc) counteracts the cytotoxic effects of proinflammatory cytokines, i.e. IL-1, TNF- $\alpha$, IL17, etc in insulin-producing cells through the reduction of nitrosative stress. ${ }^{35}$ Thus, a balance between the anti-inflammatory and the proinflammatory cytokines is of crucial importance for the prevention of pancreatic $\beta$-cell destruction. It is therefore evident that perturbation of this delicate balance in favour of pro-inflammatory cytokines is a strong possibility as the pathogenetic mechanism towards development of T2DM.

\section{Conclusion}

In conclusion, data generated through this study that can be used as normogram of incretin hormones (GIP, GLP-1) in Bangladeshi population. The findings have supported the concept of early involvement of incretin hormones in T2DM patients and thereby rationality of selecting incretin-based therapy as a first line option for T2DM individuals. However, further studies on incretin hormones and their responses to OGTT including serum pro-inflammatory and anti-inflammatory cytokines in Bangladeshi T2DM patients are warranted.

Acknowledgments: The authors would like to thank Mr. Taposh K Datta, Senior Medical Technologist and $\mathrm{Mr}$ S. M. Nawjes Ali, Laboratory Technologist-cum-Computer Operator at MRU, MHWT, Dhaka, Bangladesh for supporting with laboratory analyses and computer composing of the manuscript respectively. The authors gratefully acknowledge the generous financial support of the Ministry of Science \& Technology, Government of the People's Republic of Bangladesh, Dhaka vide Research Grant Project Serial No: 31, Group Serial No: 270, Year: 2012-2013.

\section{References}

1. Rodbard HW, Blonde L, Braithwaite SS, Braithwaite SS, Brett EM, Cobin RH et al. 
American Association of Clinical Endocrinologists medical guide lines for clinical practice for the management of diabetes mellitus. Endocr Pract. 2007: 13 (Suppl 1): 1-68.

2. International Diabetes Federation: Diabetes Atlas. Brussels. IDF, 2010.(http://www.diabetesatlas.org). Cited in: Fakhoury WKH, LeReun C, Wright D. A meta analysis of placebo-controlled clinical trials assessing the efficacy and safety of incretinbased medication in patients with type 2 diabetes. Pharmacology. 2010; 86: 44-57

3. Holst JJ, Gromada J. Role of incretin hormones in the regulation of insulin secretion in diabetic and nondiabetic humans. Am J Physiol Endocrinol Metab. 2004; 287: E199-E206.

4. Hare KJ, Vilsbøll T, Holst JJ, Knop FK. Inappropriate glucagon response after oral compared with isoglycemic intravenous glucose administration in patients with type 1 diabetes. Am J Physiol Endocrinol Metab. 2010; 298: E832-E837.

5. Nauck M, Stöckmann F, Ebert R, Creutzfeldt W. Reduced incretin effect in type 2 (non-insulindependent) diabetes. Diabetologia. 1986; 29: 46-52.

6. Knop FK, Vilsbøll T, Højberg PV, Larsen S, Madsbad S, Volund A, et al. Reduced incretin effect in type 2 diabetes: cause or consequence of the diabetic state? Diabetes. 2007; 56: 1951-59.

7. Wu T, Rayner CK, Jones $\mathrm{K}$, Horowitz $\mathrm{M}$. Dietary effects on incretin hormone secretion. Vitam Horm. 2010; 84: 81-110.

8. Cho YM Kieffer TJ. K-cells and glucosedependent insulinotropic polypeptide in health and disease. Vitam Horm. 2010; 84: 111-50.

9. Yavropoulok MP, Yovos JG. Central regulation of glucose-dependent insulinnodropic polypeptide secretion. Vitam Horm. 2010; 84: 185-210.

10. Hellstorm PM. Glucagon live peptide-1: Gastrointestinal regulatory role in metabolism and motility. Vitam Horm. 2010; 84: 319-29.

11. Toft-Nielsen M, Damholt MB, Madsbad S, Hilsted LM, Hughes TE, Michelsen BK, et al. Determinants of the impaired secretion of glucagon-like peptide-1 in type 2 diabetic patients. J Clin Endocrinol Metab. 2001; 86: 3717-23.

12. Kreymann B, Williams G, Ghatei MA, Bloom SR. Glucagon-like peptide-1 7-36: a physiological incretin in man. Lancet. 1987; 2: 1300-1304.

13. Vilsbøll T, Krarup T, Deacon CF, Madsbad S, Holst JJ. Reduced postprandial concentrations of intact biologically active glucagon-like peptide 1 in type 2 diabetic patients. Diabetes. 2001; 50: 609-13.

14. Vaag AA, Holst JJ, Vølund A, Beck-Nielsen HB. Gut incretin hormones in identical twins discordant for non-insulin-dependent diabetes mellitus (NIDDM): evidence for decreased glucagon-like peptide 1 secretion during oral glucose ingestion in NIDDM twins. Eur J Endocrinol. 1996; 135: 425-32.

15. Nyholm B, Walker M, Gravholt $\mathrm{CH}$, Shearing OA, Sturis J, Alberti KG et al. Twenty-four-hour insulin secretion rates, circulating concentrations of fuel substrates and gut incretin hormones in healthy offspring of type II (non-insulin-dependent) diabetic parents: evidence of several aberrations. Diabetologia. 1999; 42: 1314-23.

16. Vollmer K, Holst JJ, Baller B, Ellrichmann M, Nauck MA, Schmidt WE et al. Predictors of incretin concentrations in subjects with normal, impaired, and diabetic glucose tolerance. Diabetes. 2008; 57: 678-87.

17. Ahern Bo, Carr RD, Deacon CF. Incertin hormone secretion over the day. Vitam Horm 2010; 84: 204-20.

18. Miki T, Minami K, Shinozaki H, Matsunmura K, Saraya A, Ikeda H et al. Distinct effects of glucosedependent insulinotropic polypeptide and glucagon-like peptide-1 on insulin secretion and gut motility. Diabete.s 2005; 54: 1056-63.

19. Holst JJ, Knop FK, Vilsboll T, Krarup T, Madsbad $S$. Loss of incretin effect is a specific important and early characteristic of type diabetes. Diabetes Care. 2011; 34 (Suppl. 2): S251-S257.

20. Meier JJ, Nauck MA. Is the diminished incretin effect in type 2 diabetes just an epiphenomenon of impaired beta-cell function? Diabetes. 2010; 59: 1117-25.

21. Nauck MA, El-Ouaghlidi A, Gabrys B, Hucking K, Holst JJ, Deacon CF et al. Secretion of incretin hormones (GIP and GLP-1) and incretin effect after oral glucose in first-degree relatives of patients with type 2 diabetes. Regul Pept 2004; 122: 209-17.

22. Meier JJ, Gallwitz B, Askenas M, Vollmer K, Deacon CF, Holst JJ et al. Secretion of incretin hormones and the insulinotropic effect of gastric inhibitory polypeptide in women with a history of gestational diabetes. Diabetologia. 2005; 48: 1872-81.

23. Vilsbøll T, Knop FK, Krarup T, Johansen A, Madsband S, Larsen S et al. The pathophysiology of diabetes involves a defective amplification of the late-phase insulin response to glucose by glucosedependent insulinotropic polypeptide-regardless of etiology and phenotype. J Clin Endocrinol Metab. 2003; 88: 4897-4903. 
24. Hansen KB, Vilsboll T, Bagger JI, Holst JJ, Knop FK. Reduced glucose tolerance and insulin resistance induced by steroid treatment, relative physical inactivity, and high-calorie diet impairs the incretin effect in healthy subjects. J Clin Endocrinol Metab. 2010; 95: 3309-17.

25. Knop FK, Aaboe K, Vilsboll T, Madsbad S, Holst JJ, Krarup T et al. Reduced incretin effect in obese subjects with normal glucose tolerance as compared to lean control subjects (Abstract). Diabetes. 2008; 57: A410.

26. Kim H-J, Higashimori T, Park S-Y, Choi H, Dong J, Kim Y-B et al. Differential effects of interleukin6 and -10 on skeletal muscle and liver insulin action in vivo. Diabetes. 2004; 53: 1060-67.

27. Muller S, Martin S, Koening W, HanifiMoghaddam P, Rathman W, Haastert B, et al. Impaired glucose tolerance is associated with increeased serum concentrations of interleukin-6 and co-regulated acute-phase proteins but not TNFalpha or its receptor. Diabetologia. 2002; 45: 805-12.

28. Esposito K, Nappo F, Marfella R, Giughano G, Giughano F, Ciotola $\mathrm{M}$ et al. Inflammatory cytokine concentrations are acutely increased by hyperglycemia in humans: role of oxidative stress. Circulation. 2002; 106: 2067-72.

29. Nappo F, Esposito K, Cioffi M, Giughano G, Mohnari AM, Paolisso G et al. Postprandial endothelial activation in healthy subjects and type 2 diabetic patients: role of fat and carbohydrate meals. J Am Coll Cardiol. 2002; 39: 1145-50.
30. Dandona P, Aljada A, Mohanty P, Ghanim H, Hamouda W, Assian E et al. Insulin inhibits intranuclear nuclear transcription factor kappaB and stimulates lkappaB in mononuclear cells in obese subjects: evidence for an anti-inflammatory effect? J Clin Endocrinol Metab. 2001; 86: 3257-65.

31. Manning PJ, DeJong SA, Sutherland WH, McGarth M, Hendry G, Williams SM et al. Changes in circulating Postprandial proinflammatory cytokine concentrations in dietcontrolled type 2 diabetes and the effect of ingested fat. Diabetes Care. 2004; 27: 2509-11.

32. Westwell-Roper C, Dai DL, Soukhatcheva G, Potter KJ, van Rooijen N, Ehses JA et al. IL-1 blockade attenuates islet amyloid polypeptideinduced proinflammatory cytokine release and pancreatic islet graft dysfunction. J Immnol. 2011; 1872755-65.

33. Krogh-Madsen R, Plomgaard P, Moller K, Mittendorfer B, Pedersen BK. Influence of TNF- $\alpha$ and IL-6 infusions on insulin sensitivity and expression of IL-18 in humans. Am J Physiol Endocrinol Metab. 2006; 291: E108-E114.

34. Salliman CC, Kelher MR, Gamboni-Robetson F, Hamiel C, England KM, Dinarello CA et al. Tumor necrosis factor- $\alpha$ causes release of cytosolic interleukin-18 from human neutrophils. Am J Physiol Cell Physiol. 2010; 298: C714 - C724.

35. Souzal KLA, Gurgul-Convey E, Elsner M, Lenzen $\mathrm{S}$. Interaction between pro-inflammatory and antiinflammatory cytokines in insulin producing cells. J Endocronol. 2008; 197: 139-50. 